Fig. 16, 17. Fronduduarta Archtactana, D'Orbigny.

A narrow form of $F$. complanata, Defrance, of which there is an endless series of modifications. These are really chevron-chambered Nodosariæ. Frondiculariæ are common in the Gault, Chalk-marl, and Chalk, and occasionally are found abundant in the Tertiary beds, and are not wanting in some parts of the existing seas. I'ig. 17 is an edge-view.

Fig. 18, 19. Vaginduina costutata, Reuss.

A variable Nodosarian form, abundant in the Gault and Chalk-marl ; rare or wanting in the Chalk. Fig. 18 is a view of the edge, which is as variable in thickness as the shell is in its other measurements.

Fig. 20, 21, 22. Frondicularia Cordat, Reuss.

Frondicularix, or flattened, chevron-celled Nodosarix, vary continually as to the length of the backward elongations of the cells, as the two figured specimens (from the Chalk-marl or the Gault) here show. When they commence with a spiral arrangement of the cells, they are known as Flabellinæ; and excepting in this point, there is little or no distinction between Fig. 20 and D'Orbigny's Flabellina rugosa ; indeed Fig. 22 shows a little eccentricity of the first chamber. Frondicularia is to Flabellina as Nodosaria is to Marginulina and Vagulina. Fig. 21 is an edge-view.

Fig. 23, 24. Dentalina gracilis, D'Orbigny.

A variety of the world-wide $D$. communis, D'Orbigny, which occurs in all geological formations from the Palæozoic upwards. D. communis itself is a feeble form of Nodosaria Raphanus. Fig. 23 is the end-view, showing the aperture.

In the above remarks I have incorporated much information derived from $\mathrm{my}$ friend Mr. W. K. Parker.

\title{
CORRESPONDENCE.
}

\section{Causes of Cosmical Changes of Temperature on our Planet.}

That the vine, the walnut, the plane-tree, etc. etc., once flourished within the Arctic Circle, and that Mount Lebanon was for a long period covered with ice and snow, are facts inexplicable by any meteorological causes now in action, every geologist of the present day I believe admits. The question is to what causes, not now meteorologically evident, are we to attribute the great changes of temperature on our planet, which have extended over such long periods as those recorded by the unquestionable and wellestablished testimony of glaciation. Must we carry our solar system into remote regions of space in order that we may theorize on cosmic changes of temperature, or can we explain these truly wonderful facts by some changes in our own planetary motions, such as our earth getting into a zone of asteroids, to changes in the sun's atmosphere, either as to surface or intensity, as already published by Mr. Mackie, in a former number of the 'Geologist'? With regard to the theory of the earth passing through hot and cold regions of space, Mr. Mackie asks, "If heat be confined to matter, how can we speak of hot and cold regions of space, where by that very admission neither heat nor cold can be?" The reply to this question is not difficult. Matter cannot exist without space, but space can exist without matter. By hot and cold regions of space, I could only mean those portions of space occupied by matter, for where there is no matter there could be no temperature, neither hot nor cold as sensations, nor caloric as a material condition; for whether heat be a fluid or a wave, it can have no existence in pure space, pure space being a negation of everything that is 
material. The thermal portion of space must therefore be material that is occupied by matter. There can be no absolute void or pure space between us and any visible star, no matter how remote; even though its distance be so immense that the courier ray that now announces to our senses its existence, may have started on its errand thousands of millions of years ago, travelling all that time at the rate of a hundred and seventy thousand miles a second, still in the immense, the inconceivable space so run over by the luminous messenger, no absolute void could have existed, otherwise the star must be invisible to us.

Mr. Mackie is therefore right in stating "that if heat be confined to matter, how can we speak of hot and cold regions of space?" but he should have added pure or empty space where no matter exists, as I only meant those portions of space occupied by matter surrounded by and floating in a thermal ocean; for whether heat be a fluid or a wave, we cannot expect to find the causes of telluric changes of temperature by travelling into regions of space where nothing exists, where there is no entity but nought," where death is life." Mr. Mackie says (last number of "Geologist"), "if the sun moves on with his surrounding worlds, these will all travel onwards together in the same ethereal material envelope; and therefore, unless the supposed hot and cold regions of space have temperatures of much higher or much lower degrees than the general temperature of the solar region, the effect would be imperceptible." It is evident that the portions of space so traversed by our solar system at the rate of $57 \frac{1}{2}$ miles a second, moving towards the constellation Hercules, must be material, for so far as we can see any object in the universe, between us and that object there can be no absolute void or pure space, otherwise it must be invisible. Now it is clear that the regions of space occupied by matter cannot be of the same temperature, as the causes that generate light and heat are neither uniform in intensity nor distance. The path traversed by our solar system in space therefore cannot be isothermal.

It is not likely that our solar system is travelling through space surrounded by the same ethereal envelope, as Mr. Mackie seems to think, for this would be, supposing that outside this ethereal envelope nothing existed but pure space, an assumption quite opposed to the facts and reasons already stated. Besides, whether heat be a fluid or a wave, in either case it must be subject to the ordinary influences of physical agencies; therefore the same condition of matter constituting uniformity of temperature could not follow and surround our solar system in its travels through space.

Tubridge, July $19 t h, 1863$.

Datio Lestie, M.D.

\section{The Portland Fissures.}

SIR,-I hope you will allow me to correct a mistake which you hare made in your remarks on my last letter, in saying that my theory was that of "the deposition of the extinct animals in cares before the cares existed." On the contrary, I said that I was of opinion that all bonecaves were only formed by the animal remains embedded in the limestone deposit before its consolidation, and, consequently, before the existence of any caves in it.

The question with respect to the Portland and Oreston fossils is entirely dependent on the truth of certain facts. First, with respect to the Portland fossils, can the statement of Captain Manning, of the 'Willis's 